\title{
Hybrid concrete: improved processes and performance
}

\section{P. S. Barrett}

This paper presents the results of a study of three very successful Hybrid* concrete projects. Supply chain analyses are described and, in the event, the situations found are typified as networks. Problem areas are identified together with various illustrations of good practice, with a particular stress on the necessity for intensive and effective informal communications. The particular problems attendant on the design side of the process, rooted in role confusion and a lack of design fixity are highlighted. This links to the suggestion that as the knowledge of Hybrid systems becomes better understood and is more fully communicated through codification then many of these problems should evaporate. That is, Hybrid can move from being a disruptive technology and become a sustaining technology for the industry and its clients.

\section{CONTEXT AND OBJECTIVES}

The objectives of the project reported in this paper are given below.

- To identify the salient criteria for contractors in their choice and use of Hybrid systems.

- To identify a limited number of optimal generic Hybrid systems.

- To identify the appropriate situations for the use of each generic Hybrid system.

- To identify possible process improvements for each generic Hybrid system.

The work on the first objective resulted in the criteria summarised in Table 1. ${ }^{1}$ This includes a broad classification of the likely owner of the given criterion, its effect as a driving or restraining force and its focus on either the product or the process. Also included is a brief illustration of the sort of factors included under each criterion. The criteria are broadly ordered from driving forces that carry benefits for various stakeholders, to restraining forces. This reflects various perceived advantages and disadvantages of Hybrid. For example designers are likely to get excited about the aesthetic and functional possibilities of Hybrid, but to be held back by their lack of confidence, owing to a dearth of good design guidance and doubts about the industry's capacity to build to

${ }^{*}$ Hybrid is taken to represent structural systems combining in situ and pre-cast concrete. a high standard. Speed of construction is another benefit designers share an interest in with contractors, but the latter also value the enhanced safety of many Hybrid systems and, where they get the opportunity, the chance to innovate in design and to enhance buildability. The driving forces will be of varying importance to different clients so reinforcing or diminishing their importance to other project participants.

These results supported other work focused on the second and third objectives, but also raised issues that highlighted the importance, and often problematic nature, of process issues, the topic of the fourth objective, and the main focus of this paper. ${ }^{\dagger}$

\section{METHODOLOGY}

In earlier parts of the project key participants in a number of Hybrid projects had been interviewed to develop the above performance criteria and these had been used to select five generic systems that appeared to maximise the advantages of this sort of construction. The importance of process issues to realising the benefits of the systems had become clear and so to pursue this aspect in more detail a study was carried out of three specific, completed Hybrid projects. These displayed similarities with two of the generic systems and were held to be successful Hybrid projects. This study took as a starting point any one participant in the given project who then gave other contacts upstream and downstream through a snowballing technique. Each player was asked questions through telephone interviews, which took between twenty minutes and one hour, concerning the communications that took place and the respondent's perceptions of the clarity of the requirements they were charged with meeting and their degree of success in this context. The standard interview format is given as an appendix to this paper. The analysis provided a view on the ways in which the problems of supply chain complexity can arise and the ways in which the positive characteristics of Hybrid can be maximised.

In order to construct a standard interview format it was first necessary to identify the sort of questions that should be asked. There is little work on supply chains in construction, ${ }^{3}$ but the work that there is tends to concentrate on logistics from a materials supplier's point of view. However, recent work in the general supply chain field demonstrates a shift towards softer aspects, such as customer satisfaction and other service-based

${ }^{\dagger}$ The compiled results of the whole project, of which this paper reports only a part, are available as Goodchild (2001). 


\begin{tabular}{|ll|}
\hline Performance criteria & Descriptive factors \\
\hline Aesthetics & What you see is what you get' (WYSIWYG) \\
Designer - driving force & High quality fair-faced finishes \\
End product & Unusual exposed structural forms \\
Function & Environmental performance (thermal mass, plant /finishes) \\
Designer - driving force & Structural stability (in situ cores) \\
End product & Accurate, stable floors /structures \\
& Fire resistance \\
Speed & Parallel working (in situ and pc) \\
Designer and contractor - & Large components \\
driving force & Self-finished \\
Process & Platform for next stage \\
Responsive & Industry can provide early stage interactive design contribution \\
Designer and contractor - & Prototype development possible (mock-ups, trials, samples, etc) \\
driving force on innovative & Evidence of latent capacity \\
projects - Process & \\
Safe & High percentage in factory environment \\
Contractor - driving force & Clean and tidy site \\
Process & Fewer personnel on site \\
& Successive working platforms provided \\
Integrated & Need for integration between pc and in-situ \\
Designer and contractor - & Need for simplified relations between designers \\
driving and restraining forces & Need for trust and efficient approvals \\
Process & Need for effective ongoing planning \\
Buildability & Good for restricted sites \\
Contractor - driving and & Interfaces and connections well designed and flexible \\
restraining forces & Realistic tolerances \\
Process & Supported by 'simple' design and repetition \\
Confidence & Need for good design guidance (BS, NBS, trade literature) \\
Designer - restraining force & Need for 'as built' to equate with theory \\
Process & Need for industry capacity to do work (qualified, experienced) \\
& \\
Table I. Key performance criteria for the selection and use of Hybrid systems \\
\hline
\end{tabular}

Applying this approach to a practical situation does rather complicate matters, not least because any given supplier is nearly always a customer to someone upstream as well and vice versa!

The construction supply chain for structural frames is populated with likely players in Fig. 2 and the idea, drawn from Harland, is shown of Requirements passing upstream as a process chain and Performance travelling downstream as a supply chain.

These ideas are reflected in the standard interview format devised.

\section{RESULTS}

Before considering the individual projects, the general findings will be set out so that the approach taken is clarified. Fig. 3 is a partial model of part of one project showing the clarity with which requirements were perceived to be communicated by each party and their respective

issues. This reflects a deeper interest in relationships and the perception gaps that can undermine their effectiveness. Grönroos, ${ }^{4}$ in the service industry literature, presented this several years ago as the expectation-perception gap model. Linking this type of thinking to supply chain ideas results in Harland's ${ }^{5}$ model, given as Fig. 1. This identifies several gaps, both between the customer and the supplier and within each party. For this analysis the focus is on mismatches 1 and 2, which treat, respectively, differences in perception of requirements and performance between the parties.

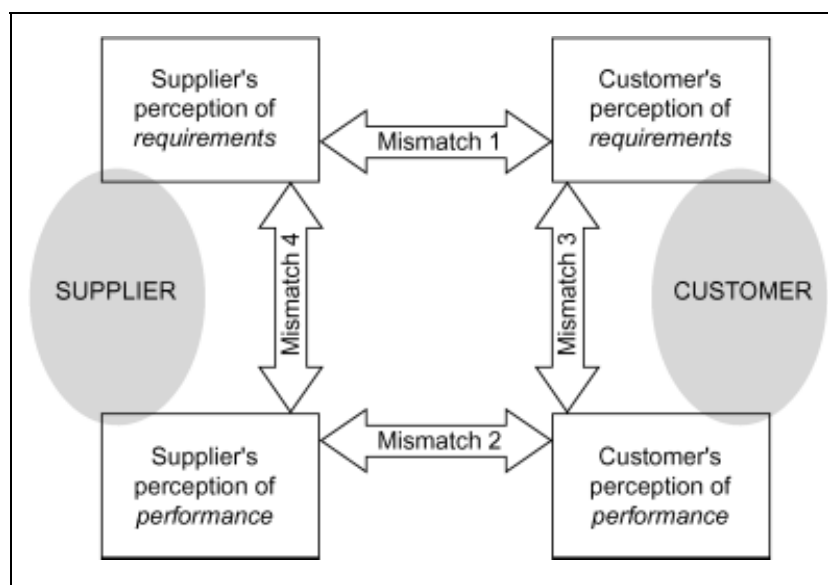

Fig. I. Harland's mismatch tool perceptions of performance achieved. From this it can be seen that there is more of a network than a chain, especially at the design team end. This picture would be even more complicated if all of the design team were shown together with the inputs and cross-checking between the specialist and the various designers. So, without any detailed analysis it is possible to say that a simple supply chain view is insufficient to capture the complexity of the situations met in, at least, this type of construction. A network of interconnected players with complex flows of requirements and performance are found. This is especially so on the design side where, for instance, it was difficult to pin down who was customer to who within the design team, none of whom seemed to really recognise the construction manager as their customer. In the end a pragmatic approach was taken where the architect was taken to be the engineer's customer for aesthetics and the QS for costs. To map this process was very difficult.

Whether it has to be so complex is another question. Where the client's requirements are very complex, and maybe unclear, a joint problem-solving approach is perhaps to be expected, but it should involve all with relevant know-how to contribute. Where the brief is more certain then such complexity in the supply network is almost certainly a fruitful place to look for simplification and increased efficiency and effectiveness. This would apply on projects that were using well-understood, intelligently detailed schemes, the performance characteristics 


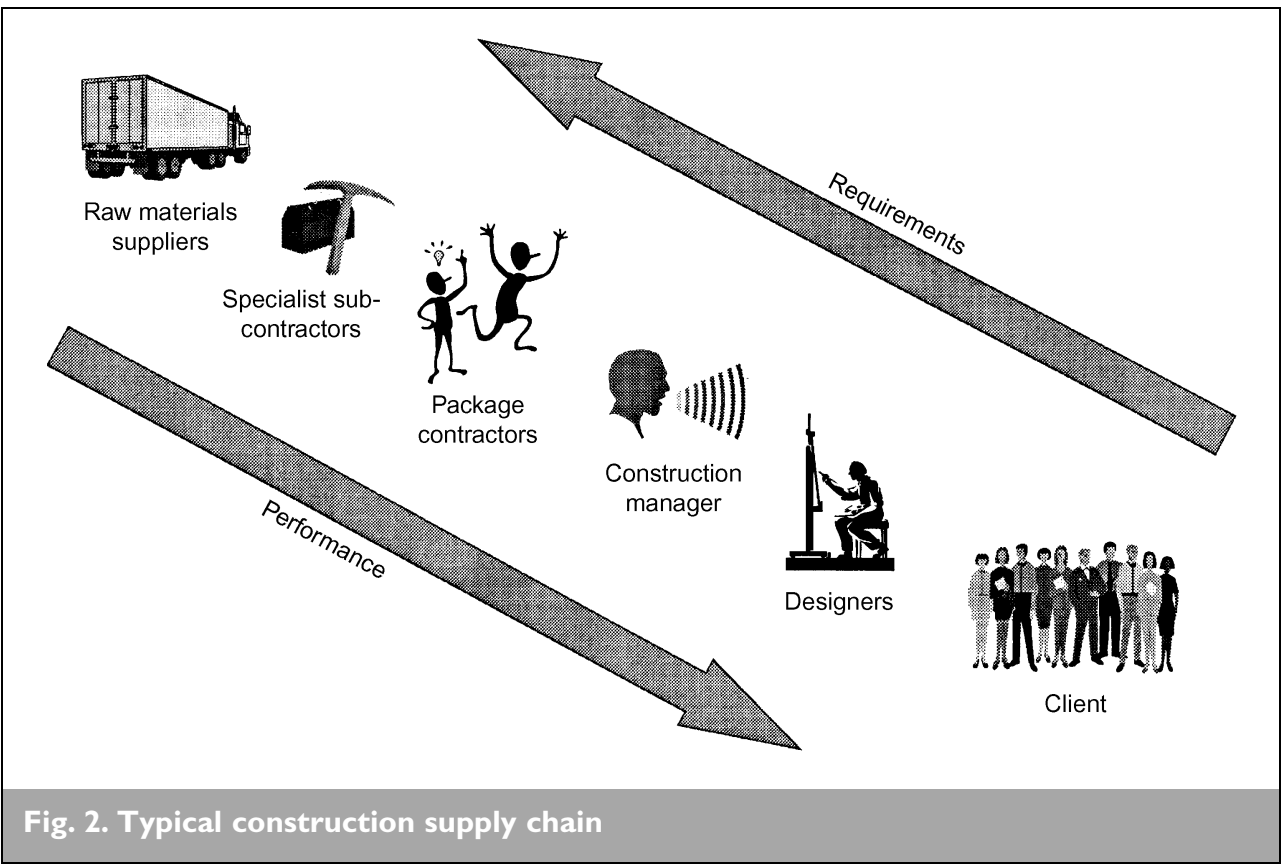

greatest uncertainty. The normal logistical supply chain problems are relatively straightforward in comparison and the supply network takes steps to contain the uncertainty with which it is confronted.

The specific projects studied were themselves atypical in that they were considered to be very successful projects and, except for the last case, they were very large projects. This means that problems of complexity could be expected to be exacerbated, but some interesting solutions should be evident. Tables 2, 3 and 4 summarise the interview data collected on the projects.

Each line represents one link

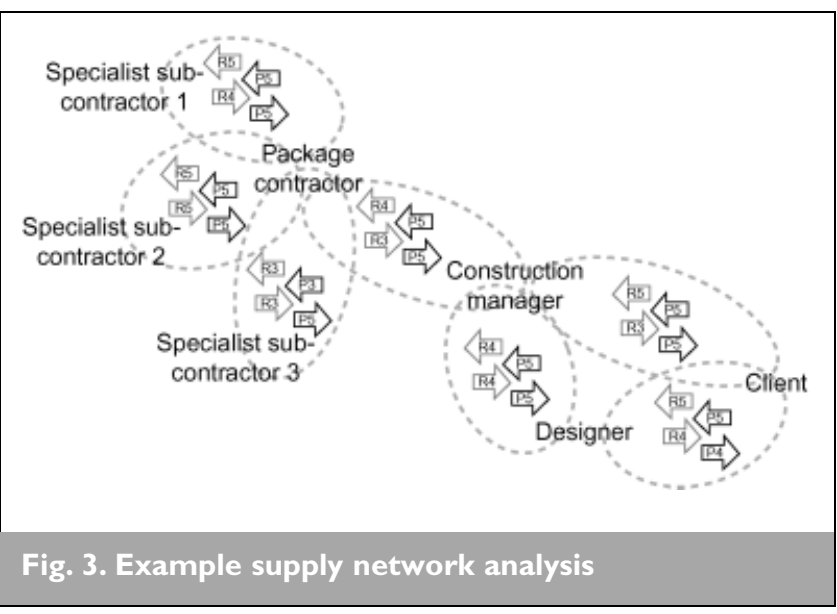

of which were accepted by all parties involved. A lot of the problems could then be designed out by a key designer in command of experienced-based information usually locked up in the brains of various designers. This is a good argument for the development and continuous improvement of generic schemes for the industry.

Interestingly, when specialist sub-contractors were quizzed about their relationships with their materials suppliers a picture of relative stability emerged, sometimes based on rolling twelve month negotiated agreements. This aspect is not highlighted in the detailed analyses that follow as only relationships where both sides were interviewed are given, however, for instability to increase as one progresses downstream (see Fig. 2) towards the 'ultimate' customer, or client, is the opposite of what normal supply chain theory predicts. In a review of the literature around the chain view, Harland ${ }^{5}$ reports systems dynamics studies that suggest that "upstream businesses suffer greater volatility and "noise" than do downstream businesses (the Forrester Effect)', driven by the 'guessing game' ${ }^{, 6}$ suppliers have to play. This highlights the atypical situation in construction where, what is to be built and what design solution is going to be used to achieve it are the areas of in the supply network of the particular project, viewed from both the customer's and the supplier's perspective. The columns headed Global Requirements give phrases typifying their respective understandings of the suppliers' remit. The Correlation column that follows puts a rating to the correspondence between the parties' views. The next three columns give the parties' ratings about the clarity with which the customers' requirements were expressed and a rating of the correlation between these views. The last three columns do the same for the performance achieved by the supplier.

\section{I. Project I}

This project was a large multi-storey car parking complex with composite pre-cast hollow core floor units simply supported by in situ post-tensioned beams and cast in situ columns.

Analysing Table 2 from left to right, there is a consistently high correlation between the customer's and supplier's views with two exceptions that score 'moderate'. Both of these reflect some disparity about the perceived scope of design responsibility. The first is seen hierarchically by the architect and more on a team basis by the construction manager. The other varies on the scope of the work: beams against reinforcement to beams.

In terms of the clarity with which the customer's requirements were communicated there is a high proportion of good/very good scores and the correlations of customers' and supplier's assessment are very positive, with one 'moderate'. In this instance, the client felt a clear brief was given at the start, but the construction manager found the high incidence of subsequent changes problematic. The lower ratings for clarity of requirements broadly reflect the occasions when it was "not possible' to attain great clarity. The project was innovative in several respects, but was also developing very rapidly and often agreement and information were chasing physical progress. This situation was generally recognised by the various parties and rapid, fluid, sometimes informal, mechanisms were used to cope. The various parties saw this as a practical necessity that they 


\begin{tabular}{|c|c|c|c|c|c|c|c|c|c|}
\hline \multirow{2}{*}{ Customer - Supplier relationship } & \multicolumn{3}{|c|}{ Global requirements } & \multicolumn{3}{|c|}{ Clarity requirements } & \multicolumn{3}{|c|}{ Achieved performance } \\
\hline & Customer's view & Supplier's view & Corr.* & Cust. view ${ }^{\dagger}$ & Supp. view ${ }^{\dagger}$ & Corr. & Cust. view ${ }^{\dagger}$ & Supp. view ${ }^{\dagger}$ & Corr. ${ }^{\star}$ \\
\hline $\begin{array}{l}\text { Client - Designer (architect) } \\
\text { (refs I/9 - I/10) }\end{array}$ & Get planning consent! & $\begin{array}{l}\text { Produce a scheme to meet client's } \\
\text { requirements and satisfy planners. }\end{array}$ & 4 & 5 & 4 & 4 & 5 & 4 & 4 \\
\hline $\begin{array}{l}\text { Client - Construction manager } \\
\text { (refs } 1 / 9-1 / 8)\end{array}$ & $\begin{array}{l}\text { Produce a workable design and } \\
\text { provide confidence that would } \\
\text { meet tight programme. }\end{array}$ & $\begin{array}{l}\text { Take responsibility for delivering } \\
\text { fixed price project to meet urgent } \\
\text { deadline. }\end{array}$ & 5 & 5 & 3 & 3 & 5 & 5 & 5 \\
\hline $\begin{array}{l}\text { Designer (architect) - } \\
\text { Construction manager } \\
\text { (refs } 1 / 10-1 / 8)\end{array}$ & $\begin{array}{l}\text { Detailing of design and manage- } \\
\text { ment of programme. }\end{array}$ & $\begin{array}{l}\text { Value engineer architectural design } \\
\text { to achieve savings required. }\end{array}$ & 3 & 4 & 4 & 5 & 5 & 5 & 5 \\
\hline $\begin{array}{l}\text { Construction manager - Package } \\
\text { contractor }(\text { refs } 1 / 8-1 / 1)\end{array}$ & Produce frame and foundations. & $\begin{array}{l}\text { Responsible } D+B \text { of whole } \\
\text { concrete frame and sub-structure. }\end{array}$ & 5 & 4 & 3 & 4 & 5 & 5 & 5 \\
\hline $\begin{array}{l}\text { Construction manager - Specialist } \\
\text { designer (refs } 1 / 9-1 / 7)\end{array}$ & $\begin{array}{l}\text { Detailed design of piles/steel from } \\
\text { employer's requirements. }\end{array}$ & $\begin{array}{l}\text { Design solutions for piles and } \\
\text { beams within cost and time. }\end{array}$ & 5 & 4 & 4 & 5 & $4 \cdot 5$ & 5 & $4 \cdot 5$ \\
\hline $\begin{array}{l}\text { Package contractor - Specialist } \\
\text { designer (refs I/I - I/7) }\end{array}$ & $\begin{array}{l}\text { Design drawings and reinforce- } \\
\text { ment schedules, plus information } \\
\text { to sub-specialist. }\end{array}$ & $\begin{array}{l}\text { Design frame to clients } \\
\text { requirements: cheap, fast, } \\
\text { innovative, good appearance. }\end{array}$ & 4 & 4 & 5 & 4 & 4 & 3 & 4 \\
\hline $\begin{array}{l}\text { Package contractor - Specialist } \\
\text { subi I (refs I/I - I/3) }\end{array}$ & $\begin{array}{l}\text { Concrete to agreed quality, when } \\
\text { needed - instructions on weekly / } \\
\text { daily basis. }\end{array}$ & $\begin{array}{l}\text { Specialist concrete mix design plus } \\
\text { rapid response to delivery } \\
\text { requirements. }\end{array}$ & 5 & 5 & 4 & 4 & 5 & 5 & 5 \\
\hline $\begin{array}{l}\text { Package contractor - Specialist } \\
\text { subi } 2 \text { (refs } 1 / /-1 / 4)\end{array}$ & $\begin{array}{l}\text { Steel reinforcement as required, } \\
\text { when requested. }\end{array}$ & $\begin{array}{l}\text { Supply steel to agreed schedule, } \\
\text { called off on a daily basis. }\end{array}$ & 5 & 5 & 5 & 5 & 5 & 5 & 5 \\
\hline $\begin{array}{l}\text { Package contractor - Specialist } \\
\text { subi } 3 \text { (refs } 1 / I-1 / 6)\end{array}$ & $\begin{array}{l}\text { Specialist design and installation } \\
\text { of beams. }\end{array}$ & $\begin{array}{l}\text { Design, supply and fixing of } \\
\text { reinforcing to beams. }\end{array}$ & 3 & 3 & 3 & 5 & 3 & 5 & 3 \\
\hline $\begin{array}{l}\text { Package contractor - } \\
\text { Specialist subi } 4 \text { (refs I/I - I /2) }\end{array}$ & $\begin{array}{l}\text { Guaranteed supply rate of } \\
\text { staircases and planks for direct } \\
\text { decoration. }\end{array}$ & $\begin{array}{l}\text { Call off lorry loads of components } \\
\text { to design and schedule. }\end{array}$ & 5 & 5 & 4 & 4 & 5 & 4 & 4 \\
\hline $\begin{array}{l}\text { * Correlation of 'global requirement } \\
\text { †Customer's / supplier's views of re } \\
\text { "Other correlations calculated as (5 }\end{array}$ & $\begin{array}{l}\text { ts' assessed by researchers: } 5=\text { ver } \\
\text { quirements /performance: } 5=\text { very } \\
5-(\text { difference between two views }))\end{array}$ & $\begin{array}{l}r y \text { high; } 4=\text { high; } 3=\text { moderate; } 2= \\
\text { good } ; 4=\text { good; } 3=\text { moderate; } 2=\end{array}$ & $\begin{array}{l}\mathrm{w} ; \mathrm{I}= \\
\text { or; I }=\end{array}$ & $\begin{array}{l}\text { y low } \\
\text { ry poor }\end{array}$ & & & & & \\
\hline
\end{tabular}




\begin{tabular}{|c|c|c|c|c|c|c|c|c|c|}
\hline \multirow{2}{*}{ Customer - Supplier relationship } & \multicolumn{3}{|c|}{ Global requirements } & \multicolumn{3}{|c|}{ Clarity requirements } & \multicolumn{3}{|c|}{ Achieved performance } \\
\hline & Customer's view & Supplier's view & Corr.* & Cust. view ${ }^{\dagger}$ & Supp. view ${ }^{\dagger}$ & Corr. & Cust. view ${ }^{\dagger}$ & Supp. view ${ }^{\dagger}$ & Corr. \\
\hline $\begin{array}{l}\text { Construction manager - Designer } \\
2 \text { (engineer) (refs } 2 / I-2 / 3)\end{array}$ & $\begin{array}{l}\text { Drawings and specification to } \\
\text { timetable including other consultants' } \\
\text { requirements. }\end{array}$ & Design on cost and to time. & 4 & 5 & 4 & 4 & 4 & 3 & 4 \\
\hline $\begin{array}{l}\text { Construction manager - Package } \\
\text { contractor (refs } 2 / I-2 / 4)\end{array}$ & $\begin{array}{l}\text { Completely designed concrete frame } \\
\text { including reverse engineering. }\end{array}$ & $\begin{array}{l}\text { Build to drawing and } \\
\text { specification with fixed costs. }\end{array}$ & 3 & 4 & 3 & 4 & 3 & 4 & 4 \\
\hline $\begin{array}{l}\text { Designer I (architect) - Designer } \\
2 \text { (engineer) (refs } 2 / 5-2 / 3)\end{array}$ & $\begin{array}{l}\text { Structure to meet superstructure and } \\
\text { finishes requirements. }\end{array}$ & $\begin{array}{l}\text { Planning spaces, aesthetics and } \\
\text { finishes. }\end{array}$ & 4 & 4 & 3 & 4 & 4 & 4 & 5 \\
\hline $\begin{array}{l}\text { Package contractor - Designer } 2 \\
\text { (engineer) (refs } 2 / 3-2 / 4 \text { ) }\end{array}$ & Final design to build to. & $\begin{array}{l}\text { Finalise design details for } \\
\text { adoption. }\end{array}$ & 5 & $1 \cdot 5$ & 2 & $4 \cdot 5$ & 4 & 4 & 5 \\
\hline $\begin{array}{l}\text { Package contractor }- \text { Specialist } \\
\text { designer (refs } 2 / 4-2 / 8)\end{array}$ & Re-design and detail structure. & $\begin{array}{l}\text { Provide alternative engineered } \\
\text { solution for superstructure. }\end{array}$ & 5 & 4 & 3 & 4 & 3 & 5 & 3 \\
\hline $\begin{array}{l}\text { Package contractor - Steel } \\
\text { supplier (refs } 2 / 4-2 / 10 \text { ) }\end{array}$ & $\begin{array}{l}\text { Deliver right steel at right time - } \\
\text { logistics. }\end{array}$ & $\begin{array}{l}\text { Supply, cut and bend steel to } \\
\text { schedules. }\end{array}$ & 5 & 3 & 5 & 3 & $3 \cdot 5$ & 5 & $3 \cdot 5$ \\
\hline
\end{tabular}

\begin{tabular}{|c|c|c|c|c|c|c|c|c|c|}
\hline \multirow[t]{2}{*}{ Customer - Supplier relationship } & \multicolumn{3}{|c|}{ Global requirements } & \multicolumn{3}{|c|}{ Clarity requirements } & \multicolumn{3}{|c|}{ Achieved performance } \\
\hline & Customer's view & Supplier's view & Corr.* & Cust. view ${ }^{\dagger}$ & Supp. view ${ }^{\dagger}$ & Corr. & Cust. view ${ }^{\dagger}$ & Supp. view ${ }^{\dagger}$ & Corr. \\
\hline $\begin{array}{l}\text { Client/developer }- \text { Specialist } \\
\text { consultant (refs } 3 / 2-3 / 1 \text { ) }\end{array}$ & $\begin{array}{l}\text { Engineering design of reinforcement } \\
\text { and panels, plus costing and } \\
\text { programme. }\end{array}$ & $\begin{array}{l}\text { Produce a tilt-up structure to } \\
\text { programme. }\end{array}$ & 5 & 5 & 5 & 5 & 5 & 5 & 5 \\
\hline $\begin{array}{l}\text { Specialist consultant - Contracting } \\
\text { services (refs } 3 / 1-3 / 2 \text { ) }\end{array}$ & $\begin{array}{l}\text { Provide labour and materials to carry } \\
\text { out work. }\end{array}$ & $\begin{array}{l}\text { Support design and build input, } \\
\text { mainly in terms of labour. }\end{array}$ & 5 & 5 & 5 & 5 & 5 & 5 & 5 \\
\hline
\end{tabular}


had to address. As a consequence there is no discernible relationship between lower scores in the Clarity section of the table and the Performance ratings.

The Performance ratings, in fact, are uniformly high with only two exceptions rated 'moderate'. One of these reflects a low supplier's rating owing to taking responsibility for a technical problem that was overcome, but caused the customer problems in the meantime. The customer did not even mention this problem! For the other exception the supplier's assessment greatly exceeds the customer's, but the relationship had been dogged by lack of clarity (acknowledged by both parties) owing to a high degree of innovation. The customer conceded that their negative view was coloured by an awkward dispute that had not gone their way. Generally, the Performance ratings reflect the project client's view that the project participants had been 'very good'.

Trawling through the responses it becomes clear that the project demands were tremendous and the relationships are typified by a high level of interaction: daily meetings, constant fax communications (or 'fax and build!', 'no time for letters', 'informally short-circuited', 'all decisions in meetings') and the use of radio links. It is also clear that any initial teething problems were quickly resolved. The euphemism 'a short sharp learning curve' was used by several respondents. Several of the relationships were not new, participants were working with partners they had experience of from previous projects. This clearly led to a lower level of misunderstandings. Quotations such as: 'good relationship', 'team players' and 'worked closely and successfully together' are common. This is underpinned by a high level of commitment: 'Never let down ... even at three o'clock in the morning!'

Price, as the basis for competition, was obviously prominent in the participants' minds, however, the project was, in fact, awarded to the team that appeared most capable, not necessarily cheapest, and many of the links were based on positive past experience - maybe because this can also be cost-effective. This close interaction allowed various innovative working methods to be developed.

Overall, the above analysis highlights the fact that, with only a few exceptions, the participants to the project had a good mutual understanding of their global requirements, these requirements were clearly expressed and the performance achieved was thought to be successful by all parties. The few exceptions that were given lower ratings, initially seem to spring from confusion over design responsibilities. Later clarity could not always be achieved because of inherent uncertainty. However, owing to a high level of commitment and informal communications these issues were resolved as the project progressed and the necessary innovations and flexibility were demonstrated. There was one instance of a particular problem, which led to some issues that were not resolved to everyone's satisfaction. However, the client was very happy with the outcome and this exception should not cloud the general picture of a very positive project.

\subsection{Project 2}

This project was a major headquarters complex with four storeys of office accommodation over two storeys of basement car parking. The basement was constructed using pre-cast concrete waffles, while the superstructure employed pre-cast concrete columns supporting in situ spine and edge beams which in turn supported site manufactured pre-cast floor beams, steel decking and a cast in situ structural topping.

Referring to Table 3, there is a high correlation between customer's and supplier's views with only one exception. This, as in Project 1, was connected with different perceptions of design responsibility, the construction manager expecting 'reverse engineering' and the package contractor to 'build to drawings'. This generally high level of agreement can be explained by a planning delay in the project that allowed relatively full design involving the specialist contractor, before starting on site.

For all that, the project was very large and innovative in a number of respects, but most of all it was very fast. From the Clarity of Requirements section, a number of quite low ratings are evident, reflecting the inherent uncertainty of the process, mutually accepted by the various parties: ' $\mathrm{OK}$ what [information] did have, but not enough'; 'detail changed all the time ... as design developed'; 'easy [issues] very good, hard [issues] very poor'. Only in one case does the perceived clarity of the requirements vary by two ratings. This appears to spring from perceived low levels of standardisation and delays in the information flows owing to 'design development problems' from the customer's side. From the supplier's side, this level of turbulence was taken as quite normal. The different ratings thus appear to reflect different levels of expectation (cf. Fig. 1). Maybe the creation and sharing of benchmarks could raise expectations and so performance generally. Overall, on the issue of effective communications, the impression is one of great variability with difficulties springing from ongoing design development and cascading through the project at all levels. In fact question 3(a) shown in the appendix was adapted from 'How effectively did they communicate their requirements?' to 'How effectively were they able to communicate their requirements?' to reflect the reality of this situation.

In terms of Performance there is a range of ratings from 'moderate' to 'very good', although none of the customers reported (does not include the project client) gave the top rating to any of their suppliers. Generally the suppliers rate their performance higher than do the customers. In addition, the correlations between perceptions appear to be lower at each end of the supply chain. The lower ratings as the chain approached the client seem to have sprung from difficulties handling the complexity of the project and particularly some of the design interfaces, while the contracting input is perceived to have lost momentum towards the end of the project. Interestingly, the pairing with the lowest joint clarity on requirements scored well in terms of performance. This seems to be explained, echoing Project 1 above, by a 'good working relationship' and a mutual recognition of the problems each faced.

The lower correlations upstream reflect, in one case, the difficulty of design checking routines spanning as a network from the client's design team right through to the package contractor's designer, who had significantly varied the design in the tendering process. The latter clearly felt that they had done well in the circumstances given the turbulence induced 
from downstream: "coordination problem ... design had lots of gaps'. This same pattern can be discerned in the other low performance rating. The supplier accepted the high level of uncertainty and 'responded well throughout', but the customer maybe wanted a more proactive approach, rather than a response that varied 'depending on personalities'.

Overall, scanning the pages of the interview records, a feeling of a slightly combative project comes through. The project was generally very successful in global terms, but the inevitable uncertainties springing from design development as work proceeded were not always absorbed by formal processes at the client end of the project. However, the many meetings became more informal the further one travelled from the client. Additionally, the hierarchical structure at the top could not cope with the volume of information and so, as the project proceeded, informal lateral exchanges of information were agreed with copies up the hierarchy.

\subsection{Project 3}

This was a relatively small project for a cold store including the plant room, using tilt-up construction employing composite insulated concrete wall panels.

The project is summarised in Table 4. It was very different from the first two projects-much smaller and very much less complex, with only two main players interviewed. One was the specialist consultant who provided a technical design input for the specialist system being used, but also supervised work on site and provided specialist plant. The other was both the client to the above and the provider of labour and materials. The multiple roles taken by each player highlights one approach to simplifying information flows. The consequent risk of too much reliance on one person did not, in this case, cause a problem, but was mitigated by a careful and deliberate selection process. There was clearly a high level of trust, commitment and interaction between the parties. Further, the project was perceived as something of an experiment by the customer and so cost pressure was removed.

Given the special circumstances outlined above, and the zeal of the participants, it is perhaps hardly surprising that Table 4 shows top scores for each dimension and absolute correlation in the views of the parties. However, in fairness to the respondents, the project did display various characteristics that the other case studies have highlighted as helping towards a positive outcome. The relationship was 'very interactive' and 'information sent for approval received immediate answers'. Apparently, one month was saved on an original programme of only six months. In a way the first two projects reported above suffered from their sheer scale irrespective of the system being used (although the rate of building probably could not have been achieved with more traditional approaches). This project shows how the uncertainties of an innovative approach can be absorbed very satisfactorily when not compounded by both scale and complexity. In a way the project can be seen as an indication of how some of the innovative ideas reported elsewhere in this report could be more easily made operational on smaller projects.

\section{DISCUSSION}

The case study of Project 1 illustrates the inevitable presence of uncertainty in innovative projects, even when the global requirements were well understood. This uncertainty focussed particularly on perceived design scope and responsibilities. Project 2 confirmed this issue and in this case the knock-on effect by way of the flow of changing requirements upstream through the supply network clearly caused some problems as the design evolved.

In both cases various interactive techniques were used and ultimately a high level of informal communication was relied on. This seems to have been the essence of Project 1, based to quite an extent on previous working relationships and a very high level of commitment to the project. The feeling comes over that the participants simply lived the project and this can be sensed clearly in Project 3 too. In Project 2 the migration to informal 'shortcuts' was seen as a necessary reaction to the formal systems being unable to cope. There was some reticence at being dependent on individuals, whereas this was the essence of the other projects.

All of the projects had very positive outcomes from the ultimate clients' point of view. In Projects 1 and 3 this satisfaction was generally shared throughout the project participants. Project 3 illustrates how ideas that helped participants cope in the massively complex Projects 1 and 2 can soak up problems on smaller, less inherently demanding, but no less innovative projects.

The conception of the consulting engineers being suppliers of structural designs to architects as customers with aesthetic requirements, QSs with cost requirements, etc., stood up reasonably well as a crude representation. However, the interactive and iterative nature of the design process was clearly illustrated involving not only the client's design team, but specialist designers working for package contractors and specialist sub-contractors as well. The design development and transmission can be seen as the flow of requirements upstream (Fig. 2), however, the flow is not one way in reality and cuts across traditional hierarchical and status fault lines in the industry. This fragmentation led to a lot of the uncertainty in the projects. There seems to be some doubt as to which engineers have the necessary knowledge-the consultant engineers or the contractor's engineers. This is even more confusing as on different projects these can often be the same firms-the same people acting in different roles. The solution adopted in the projects (which worked) was a high level of communications. Alternative approaches could be to encapsulate the experience of the systems so that the client's team could design more effectively in isolation or to devolve responsibility more fully so reducing the need for so much checking. Both alternatives, in principle, reduce the need to process information, and carry advantages and corresponding risks. However, it may be that the risks would not be that great if the technology was better encoded for general use and the projects in question were more normal in size and complexity.

Figure 4 suggests a web-based information platform, starting with the five generic systems, and designed to support the encoding, transmission, and continuous improvement, of know-how about Hybrid systems. The notion is that the concrete industry is highly differentiated with many small, specialist players so it is not realistic (or necessarily beneficial) 


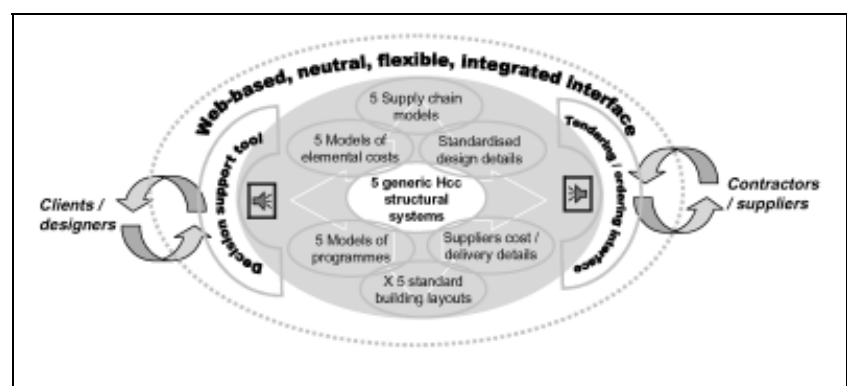

Fig. 4. Design for a web-based information platform

to impose a heavy structure on it. However, by creating a fully accessible forum on the web a market for compatible components could be created. This could be 'seeded' with the five generic Hybrid systems developed within this research project $^{2}$ for which design details, fundamental costs, programme and standard layouts exist to support designers. Contractors and suppliers could then competitively offer services and products against these standard specifications. Over time, through these interactions, improvements to the generic systems and, indeed, new systems, would be introduced as the virtual market in Hybrid ideas, products and services developed and matured.

\section{CONCLUSIONS}

The main points arising from the study are as follows.

- Larger Hybrid projects are underpinned by complex, interactive supply networks.

- Uncertainty is unavoidable in innovative Hybrid projects, especially during the process of construction.

- Stability and integration can be achieved, but high levels of communication and commitment underpinned by mutual trust are essential-formal paper-based systems alone are unlikely to cope.

- The complexity and fragmentation of the design process making up the flow of requirements upstream contrasts with the relatively well-managed logistics-oriented process downstream. This is rooted in the issue of evolving client requirements and design solutions.
- The engineering design inputs may be delivered from various points in the supply network and this can cause problems with the traditional structure of the industry.

- Implicit in the above analysis is the potential contribution of some codification of Hybrid systems so that engineers can operate without so much need for interaction. This amounts to reducing the innovation, and thus the uncertainty, inherent in the process. It is suggested that this process could be accelerated using generally available web technologies.

- For smaller, more typical projects the lower level of inherent complexity should make the take up of welldeveloped Hybrid systems simpler.

Taking Christensen's ${ }^{7}$ perspective, Hybrid can be seen as a 'disruptive technology' against the context of the more normal 'sustaining technologies' used by the industry. As such it may be that Hybrid systems will emerge in new markets with specialist value requirements and then cross boundaries as a coherent understanding of the performance characteristics of the systems emerge. It is hoped that this work will assist this process.

\section{ACKNOWLEDGEMENTS}

The author would like to thank many individuals for their support. A large number of participants in Hybrid projects in industry have given their time and first-hand knowledge always openly and enthusiastically. The project steering group gave their views and helpful feedback throughout the project. Dr Baiche of Oxford Brookes University openly shared data and contacts. My colleague Prof. Ghassan Aouad supported the work throughout. Charles Goodchild of the Reinforced Concrete Council (RCC) led the project of which this is a part with consistent attention to detail, while keeping the global objectives in focus. Through the RCC, the Department of the Environment, Transport and the Regions (DETR) provided the funding that enabled this work to be undertaken. The helpful comments of an anonymous referee resulted in improvements to the clarity of the paper. As ever any errors or misinterpretations are the responsibility of the author, but much of the credit must go to the active support provided by the above collaborators.

\section{APPENDIX - STRUCTURED TELEPHONE INTERVIEW FORMAT}

\section{Questionnaire for Supply Chain Analysis}

Project Name: Company contacted: Co. position:
Interview Reference (proj/Co) Date: Interviewee: Proj. position:

\footnotetext{
1. General backround (Co workload), and basis of competition in your part of the industry.

[Aesthetics, function, speed, confidence, easy to integrate, responsive, buildability, safe, cost]
} 
2. Role in relation to Hcc elements of frame / walls / floors on project in question?

Your package of work:

Significant players upstream and downstream based on material or information flows:

(No. below)

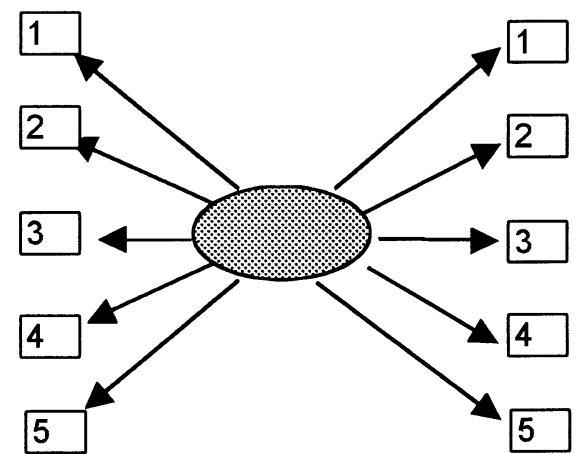

Upstream suppliers

Downstream customers

I will fax for contact details of the above parties - OK?

Your fax number please:

Views on Significant Customers

(for which Interviewee is "supplier")

Interview Reference (proj/co)

\section{"1.}

(a) What were their requirements for information and / or materials? (don't prompt)

In hard, logistical terms:

[what, where, when]

In softer, service terms:

[responsive, confidence, etc]

How were these req'ts

communicated?

How effectively were they able to

communicate their requirements?

\begin{tabular}{ccccc}
1 & 2 & 3 & 4 & 5 \\
\hline Very poor & Poor & Moderate & Good & Very good
\end{tabular}

(b) How well would you rate your performance for this customer?

Qualitatively:

Quantitively o/all:

\begin{tabular}{ccccc}
1 & 2 & 3 & 4 & 5 \\
\hline Very poor & Poor & Moderate & Good & Very good
\end{tabular}


(a) What were their requirements for information and / or materials? (don't prompt)

In hard, logistical terms:

[what, where, when]

In softer, service terms:

[responsive, confidence, etc]

How were these req'ts

communicated?

How effectively were they able to

communicate their requirements?

\begin{tabular}{ccccc}
1 & 2 & 3 & 4 & 5 \\
\hline Very poor & Poor & Moderate & Good & Very good
\end{tabular}

(b) How well would you rate your performance for this customer?

Qualitatively:

Quantitively o/all:

\begin{tabular}{ccccc}
1 & 2 & 3 & 4 & 5 \\
\hline Very poor & Poor & Moderate & Good & Very good
\end{tabular}

Views on Significant Suppliers

(for which Interviewee is "customer")

Interview Reference (proj/Co)

(for which Interviewee is "customer")

(2)




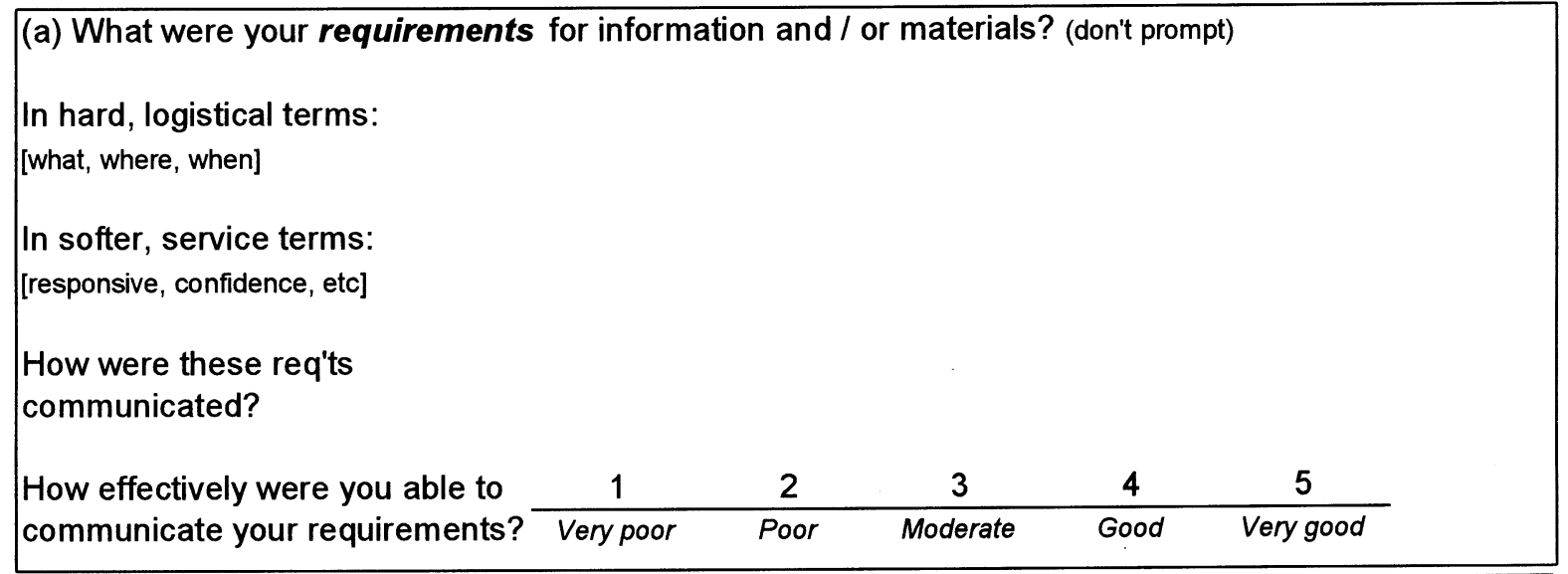

(b) How well would you rate them on their performance?

Qualitatively:

Quantitively o/all:

\begin{tabular}{ccccc}
1 & 2 & 3 & 4 & 5 \\
\hline Very poor & Poor & Moderate & Good & Very good
\end{tabular}

\section{REFERENCES}

1. BARRETT P. S. and AOUAD G. Supply Chain Analysis for Effective Hybrid Concrete Construction. In Customer Satisfaction: A Focus for Research and Practice. CIB, 1999, Publication 234, Vol. 2, pp. 566-580.

2. GoodCHILD C. H. Hybrid Construction for the UK Market: Final Report on Using Combinations of in situ and Pre-cast Concrete in Structural Frames to Achieve Better Value for UK Customers. Reinforced Concrete Council, 2001.

3. O'Brien W. J. Construction Supply Chains: Case Study, Integrated Cost and Performance Analysis. In Lean Construction (Alarcón L. (ed)). A. A. Balkema, Rotterdam,
1997, pp. 187-222.

4. GRöNROOS, C. Strategic Management and Marketing in the Service Sector. Chartwell-Bratt, Bromley, 1984.

5. HARLAND C. M. Supply chain management: relationships, chains and networks. British Journal of Management, 1996, 7, Special Issue, S63-S80.

6. TowILL D. R. A route map for substantially improving supply chain dynamics. International Journal of Manufacturing Technology and Management, 2000, 1, No. 1, 94-112.

7. CHRISTENSEN C. M. The Innovator's Dilemma: When New Technologies Cause Great Firms to Fail. Harvard Business School Press, Boston, Mass., 1997.

Please email, fax or post your discussion contributions to the secretary by I November 2003: email: daniela.wong@ice.org.uk; fax: +44 (0)20 7799 1325; or post to Daniela Wong, Journals Department, Institution of Civil Engineers, I-7 Great George Street, London SWIP 3AA. 